\title{
Perbandingan Kinerja Sensor TGS2610, MQ2, dan MQ6 pada Alat Pendeteksi Kebocoran Tabung Liquified Petroleum Gas (LPG) Menggunakan ATMega2560 \\ Rizala, Abdul Muida* ${ }^{*}$ Iklas Sanubarya
}

\author{
aProgram Studi Fisika, Jurusan Fisika, FMIPA Universitas Tanjungpura \\ Jalan Prof. Dr. Hadari Nawawi, Pontianak, Indonesia \\ *Email : muid@physics.untan.ac.id
}

\begin{abstract}
Abstrak
Pada penelitian ini telah dibuat alat pendeteksi kebocoran tabung Liquified Petroleum Gas (LPG) menggunakan mikrokontroler ATMega2560 untuk menguji kinerja sensor TGS2610, MQ2, dan MQ6. Indikator adanya gas ditunjukkan dengan bunyi buzzer, cahaya LED dan tulisan pada LCD. Berdasarkan pengujian waktu respon, diperoleh hasil 0,13 detik untuk MQ2, 0,16 detik untuk MQ6, dan 0,03 detik untuk TGS2610. Sedangkan untuk pengujian jarak diperoleh hasil yaitu, sensor TGS2610 dapat mendeteksi gas pada jarak $50 \mathrm{~cm}$, MQ2 dapat mendeteksi gas pada jarak $40 \mathrm{~cm}$ dan MQ6 dapat mendeteksi gas pada jarak $30 \mathrm{~cm}$. Berdasarkan parameter yang diuji terlihat bahwa sensor TGS2610 memiliki kinerja yang lebih baik, kemudian diikuti sensor MQ2, dan MQ6.
\end{abstract}

Kata Kunci : Sensor Gas, Kinerja Sensor, ATMega2560

\section{Latar Belakang}

Kurangnya tingkat keamanan pada pemakaian tabung Liquified Petroleum Gas (LPG), dapat menyebabkan kebocoran pada tabung LPG. LPG memiliki sifat yaitu mudah terbakar, sehingga kebocoran tabung LPG sangat beresiko tinggi terjadinya kebakaran. Oleh karena itu maka perlu adanya alat pendeteksi kebocoran tabung LPG [1].

Beberapa penelitian mengenai alat pendeteksi kebocoran tabung gas LPG telah dibuat, di antaranya adalah sebuah alat pendeteksi kebocoran tabung LPG dan metana menggunakan sensor TGS2610 sudah pernah dibuat oleh Triyandana[2]. Sebuah alat LPG Monitoring System yang terkoneksi dengan Short Message Service (SMS) menggunakan sensor MQ6 juga sudah dibuat oleh Iksal[3], dan rancang bangun pendeteksi gas dengan sensor MQ6 juga pernah dibuat oleh Putra[4].

Pada penelitian ini dilakukan pengujian kinerja sensor pada alat pendeteksi kebocoran tabung LPG, menggunakan sensor TGS2610, MQ2, dan MQ6. Ketiga sensor diuji sensitivitasnya berdasarkan parameter waktu respon dan jarak deteksi.

\section{Metodologi}

\section{a. Perancangan Sistem}

Perancangan alat terdiri atas tiga bagian utama. Bagian pertama yaitu input yang terdiri atas tiga buah sensor yaitu sensor TGS2610, MQ2 dan MQ6. Bagian kedua yaitu proses, sistem pemrosesan sinyal menggunakan arduino mega 2560 untuk memproses semua data yang diterima. Bagian ketiga yaitu output, yang terdiri dari LED yang digunakan untuk mengeluarkan cahaya sebagai indikator adanya LPG dan buzzer sebagai tanda bunyi peringatan bahwa ada LPG, serta LCD untuk menampilkan jenis dan waktu respon sensor. Diagram blok perancangan sistem dari alat dapat dilihat pada Gambar 1.

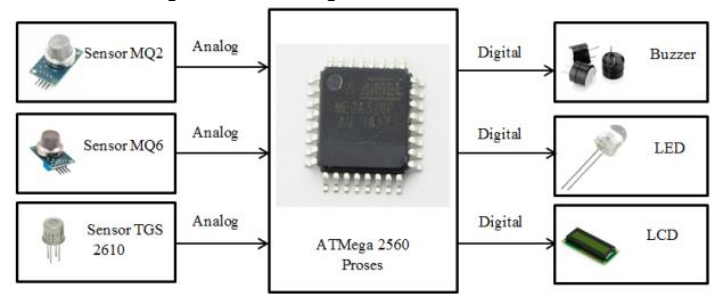

Gambar 1. Diagram blok perancangan sistem

\section{b. Perancangan Alat}

Perancangan alat pada penelitian ini dibuat seperti pada Gambar 2. Dimensi ukuran dari alat pendeteksi gas LPG adalah $(18,5 \times 12,5) \mathrm{cm}$. Ketiga sensor dirangkai dalam satu bagian. Setelah gas disemprotkan ke sensor kemudian mikrokontroler memproses, apabila ada gas LPG maka LED indikator akan menyala dan buzzer otomatis akan aktif, serta LCD akan menampilkan tulisan berupa jenis sensor dan waktu respon.

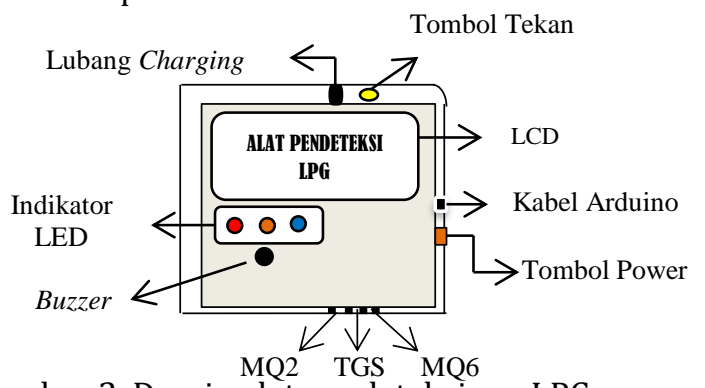

Gambar 2. Desain alat pendeteksi gas LPG 
Gambar 3 adalah alur program yang dibuat berdasarkan perancangan cara kerja alat. Pertama kali dijalankan, sistem akan melakukan proses inisialisasi input yang dihubungkan dengan perangkat luar seperti sensor, buzzer, LED, dan LCD. Jika terdapat gas LPG maka LED menyala, buzzer akan berbunyi, dan LCD akan menampilkan parameter waktu respon. Jika tidak mendeteksi gas LPG maka sistem akan kembali melakukan inisialisasi input secara terus menerus sampai mendeteksi kembali adanya gas.

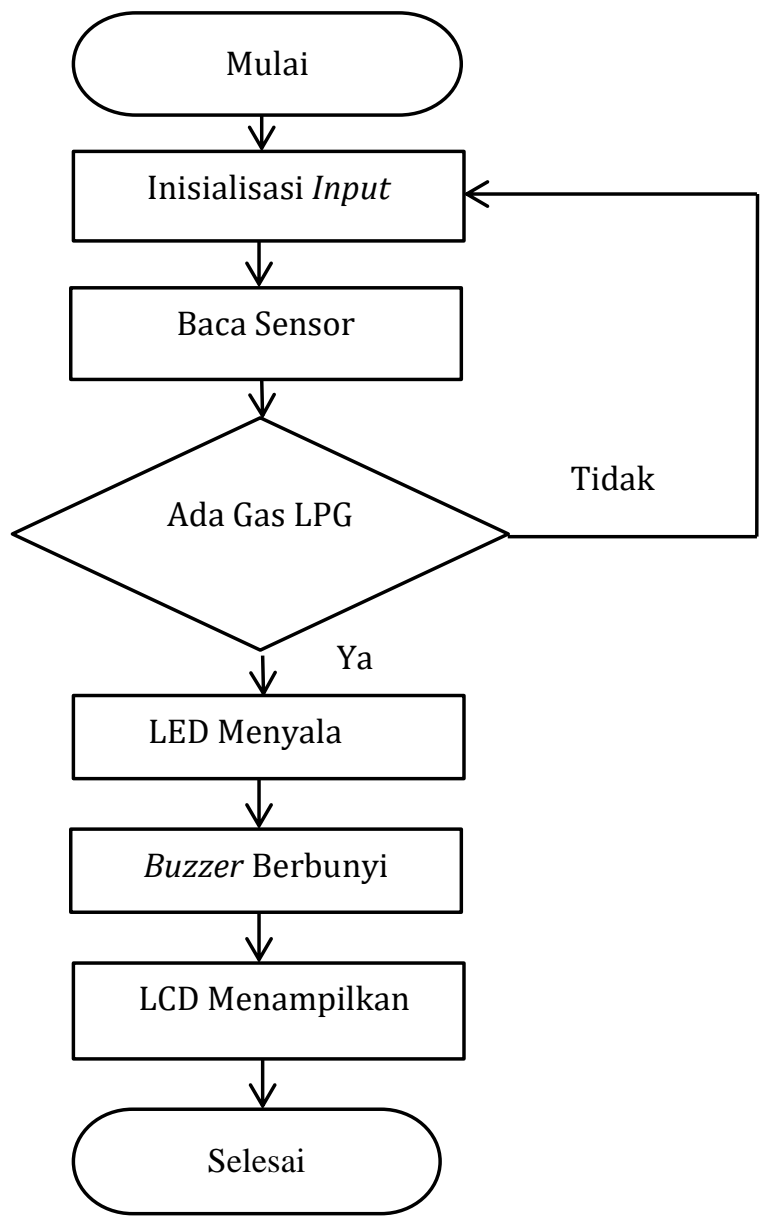

Gambar 3. Diagram alir sistem

\section{c. Pengujian dan Analisa}

Pengujian dilakukan pada dua parameter yaitu waktu respon dan jarak. Pengujian waktu respon tiap sensor perlu dilakukan untuk mengetahui kecepatan masing masing sensor pada saat digunakan untuk mendeteksi gas. Waktu sangatlah penting dalam proses pengujian suatu sensor karena semakin cepat suatu sensor mendeteksi gas maka sensor tersebut dikatakan memiliki sensitifitas yang tinggi. Jadi pada penelitian kali ini akan dilihat dari ketiga sensor yang dipakai, sensor mana yang lebih sensitif. Jarak sensor merupakan parameter kedua yang akan diteliti pada penelitian ini, jarak sensor dalam hal ini adalah ketika gas disemprotkan pada sensor, sensor mana yang masih mampu mendeteksi gas LPG ketika jarak sensor divariasikan. Hasil pengujian berdasarkan dua parameter yang diuji inilah nantinya akan didapatkan sebuah sensor yang memiliki kinerja yang baik.

\section{d. Perancangan Perangkat Keras Sistem}

Perancangan perangkat keras dalam sistem pendeteksi kebocoran tabung LPG meliputi perancangan rangkaian sensor TGS2610, MQ2, MQ6, buzzer, LED , Push Button, LCD, baterai. Gambar 4 adalah skematik rangkaian elektronika alat keseluruhan pada sistem pendeteksi kebocoran tabung LPG.

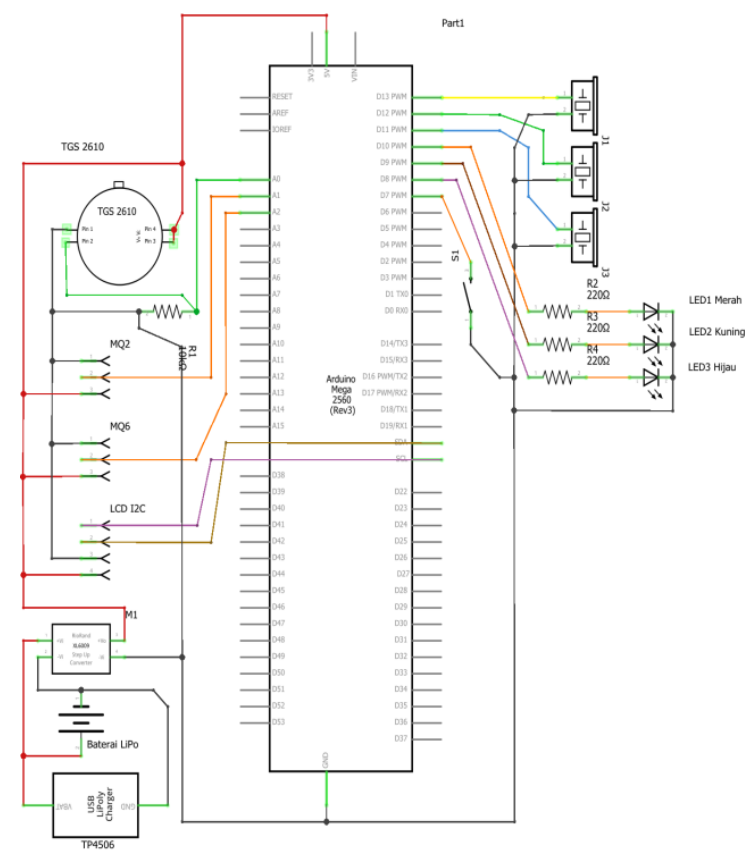

Gambar 4. Skematik rangkaian elektronika alat

\section{e. Perancangan Perangkat Lunak}

Perancangan perangkat lunak menggunakan bahasa pemrograman arduino, karena lebih praktis dan mudah dipelajari dibandingkan dengan bahasa pemrograman yang lain. Bahasa pemrograman arduino perangkat lunaknya bersifat open source serta dilengkapi dengan library yang cukup lengkap.

\section{Hasil dan Pembahasan}

\section{a. Pengujian Perangkat Keras}

Perangkat keras dalam penelitian ini dibuat dalam satu alat. Gambar 5 adalah rangkaian perangkat keras alat pendeteksi kebocoran tabung LPG. Pada alat ini terdapat beberapa bagian yang sangat penting dalam penggunannya, sehingga perlu dilakukan pengujian pada setiap bagian perangkat luar tersebut. 


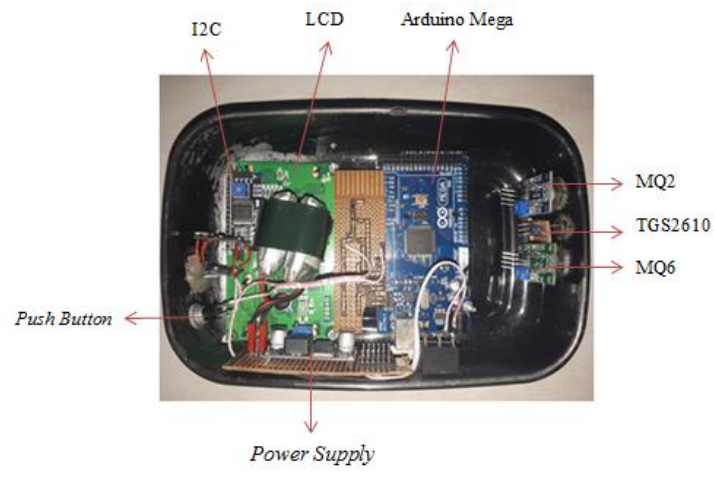

Gambar 5. Rangkaian perangkat keras alat

\section{b. Pengujian Mikrokontroler ATmega2560 dan LCD 20X4}

Pada saat pengujian awal mikrokontroler, langkah awal yang harus dilakukan adalah dengan mengunduh salah satu program. Mikrokontroler dapat digunakan apabila program yang diunduh dapat berjalan dengan baik. Setelah mengunduh program LCD, langkah selanjutnya adalah memverifikasi dan mengupload program yang akan digunakan. Apabila program ini dapat berjalan dengan baik dan lancar maka akan menampilkan tulisan di LCD seperti pada Gambar 6 [5].

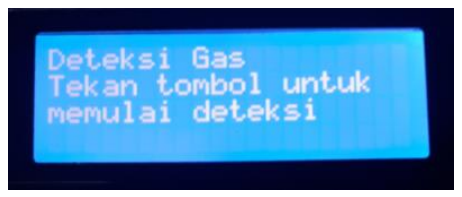

Gambar 6. Pengujian LCD

\section{c. Pengujian ADC Ketiga Sensor}

Pengujian ADC pada sensor perlu dilakukan karena ingin melihat nilai ADC dari sensor tersebut. Pengujian juga dilakukan dengan pengambilan data sebanyak empat kali, ini dilakukan untuk melihat nilai ADC sebelum ada gas dan sesudah ada gas. Pada gambar 7 dan 8 ini adalah hasil pengujian ADC sebelum dan sesudah ada gas dari ketiga sensor yang ditampilkan dalam bentuk diagram batang. Pengambilan data ADC ini diambil pada jarak $2 \mathrm{~cm}$.

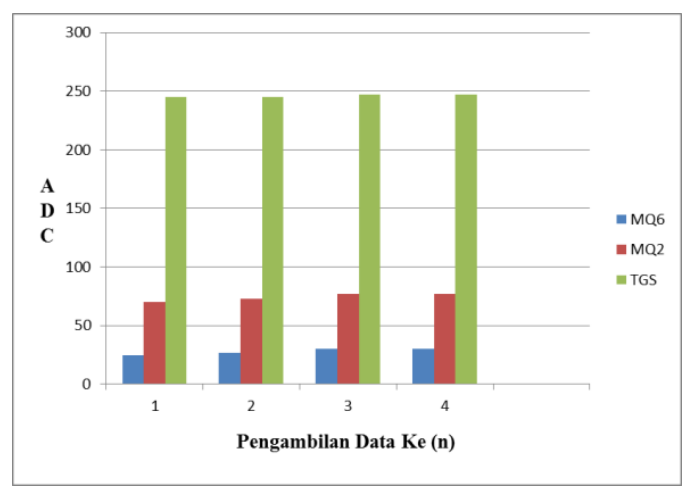

Gambar 7. Pengujian nilai ADC sebelum ada gas

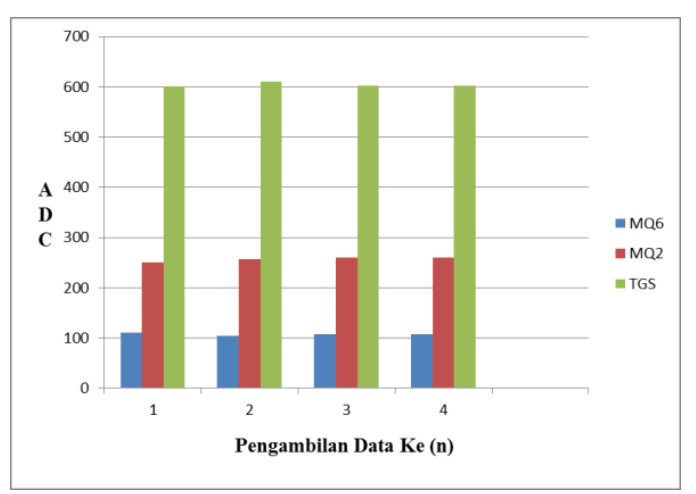

Gambar 8. Pengujian nilai ADC sesudah ada gas

\section{d. Pengujian Waktu Respon}

Pengujian waktu respon dilakukan di ruang terbuka untuk melihat seberapa besar pengaruh ruangan yang ditempati. Beberapa hal yang menjadi kendala dalam pengujian waktu respon diantaranya tidak mengetahui seberapa banyak gas LPG yang keluar dalam hal ini konsentrasinya. Untuk parameter waktu respon ditampilkan pada LCD. Pengujian ini dilakukan untuk melihat seberapa sensitif ketiga sensor akan dibandingkan pada jarak $2 \mathrm{~cm}$ dan juga seberapa cepat sensor mendeteksi adanya gas yang bocor pada tabung LPG. Gambar 9 adalah proses pengujian waktu respon.

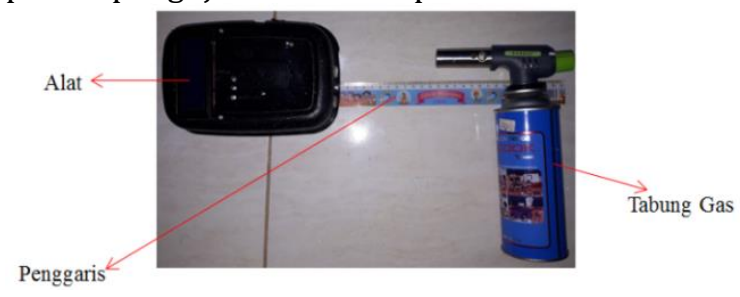

Gambar 9. Pengujian waktu respon

Pada gambar 10 adalah hasil pengujian waktu respon pada ketiga sensor yang ditampilkan dalam bentuk diagram batang. Waktu respon diukur dari pengambilan data pada jarak $2 \mathrm{~cm}$. Sensor yang menggunakan tegangan $5 \mathrm{~V}$ sangat cepat untuk mencapai suhu 50-60 $\mathrm{C}$. Elemen pemanas pada sensor umumnya butuh waktu 3 menit untuk mencapai pembacaan sensor supaya stabil [6].

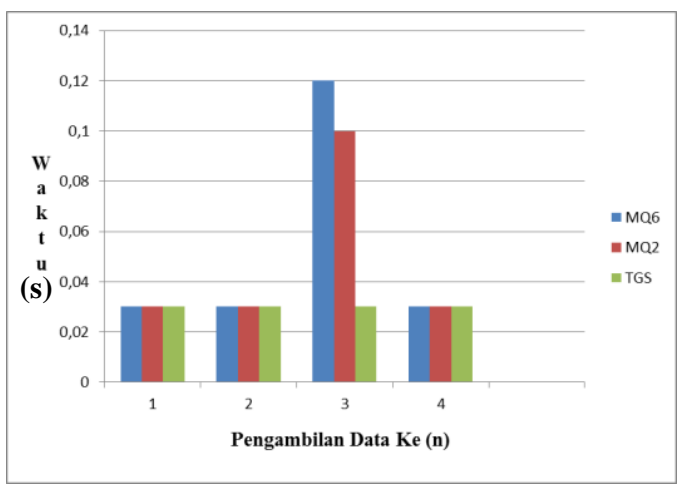

Gambar 10. Pengujian waktu respon ketiga sensor 


\section{e. Pengujian Jarak Untuk Ketiga Sensor}

Pada pengujian jarak ini dilakukan untuk melihat seberapa jauh sensor itu masih mampu menangkap adanya kebocoran tabung gas LPG. Tabel 1 adalah hasil pengujian jarak untuk ketiga sensor, semakin jauh jarak yang digunakan artinya semakin rendah konsentrasi yang akan diterima oleh sensor dan sebaliknya jika semakin dekat jarak yang digunakan maka semakin tinggi konsentrasi yang diterima sensor. Pada pengujian jarak terjauh didapatkan hasil bahwa sensor TGS2610 memiliki kinerja yang paling baik dibandingkan sensor MQ2 dan MQ6. Sensor TGS2610 mampu mendeteksi gas pada jarak $50 \mathrm{~cm}$, sedangkan sensor MQ2 dan MQ6 hanya mampu mendeteksi gas pada jarak $40 \mathrm{~cm}$ dan $30 \mathrm{~cm}$.

Tabel 1. Hasil pengujian jarak ketiga sensor

\begin{tabular}{|c|c|c|c|c|}
\hline No & Pengujian Sensor & $\begin{array}{l}\text { Parameter } \\
\text { Jarak }\end{array}$ & Indikator & Keterangan \\
\hline \multirow{6}{*}{1} & \multirow{6}{*}{$\begin{array}{l}\text { Pengujian jarak deteksi } \\
\text { pada sensor TGS2610 }\end{array}$} & $10 \mathrm{~cm}$ & $\begin{array}{l}\text { Buzzer aktif, LED nyala, } \\
\text { LCD mendeteksi }\end{array}$ & $\begin{array}{l}\text { Berhasil mendeteksi } \\
\text { gas }\end{array}$ \\
\hline & & $20 \mathrm{~cm}$ & $\begin{array}{l}\text { Buzzer aktif, LED nyala, } \\
\text { LCD mendeteksi }\end{array}$ & $\begin{array}{l}\text { Berhasil mendeteksi } \\
\text { gas }\end{array}$ \\
\hline & & $30 \mathrm{~cm}$ & $\begin{array}{l}\text { Buzzer aktif, LED nyala, } \\
\text { LCD mendeteksi }\end{array}$ & $\begin{array}{l}\text { Berhasil mendeteksi } \\
\text { gas }\end{array}$ \\
\hline & & $40 \mathrm{~cm}$ & $\begin{array}{l}\text { Buzzer aktif, LED nyala, } \\
\text { LCD mendeteksi }\end{array}$ & $\begin{array}{l}\text { Berhasil mendeteksi } \\
\text { gas }\end{array}$ \\
\hline & & $50 \mathrm{~cm}$ & $\begin{array}{l}\text { Buzzer aktif, LED nyala, } \\
\text { LCD mendeteksi }\end{array}$ & $\begin{array}{l}\text { Berhasil mendeteksi } \\
\text { gas }\end{array}$ \\
\hline & & $60 \mathrm{~cm}$ & $\begin{array}{l}\text { Buzzer nonaktif, LED } \\
\text { tidak nyala, LCD tidak } \\
\text { mendeteksi }\end{array}$ & $\begin{array}{l}\text { Gagal mendeteksi } \\
\text { gas }\end{array}$ \\
\hline \multirow{5}{*}{2} & \multirow{5}{*}{$\begin{array}{l}\text { Pengujian jarak deteksi } \\
\text { pada sensor MQ2 }\end{array}$} & $10 \mathrm{~cm}$ & $\begin{array}{l}\text { Buzzer aktif, LED nyala, } \\
\text { LCD mendeteksi }\end{array}$ & $\begin{array}{l}\text { Berhasil mendeteksi } \\
\text { gas }\end{array}$ \\
\hline & & $20 \mathrm{~cm}$ & $\begin{array}{l}\text { Buzzer aktif, LED nyala, } \\
\text { LCD mendeteksi }\end{array}$ & $\begin{array}{l}\text { Berhasil mendeteksi } \\
\text { gas }\end{array}$ \\
\hline & & $30 \mathrm{~cm}$ & $\begin{array}{l}\text { Buzzer aktif, LED nyala, } \\
\text { LCD mendeteksi }\end{array}$ & $\begin{array}{l}\text { Berhasil mendeteksi } \\
\text { gas }\end{array}$ \\
\hline & & $40 \mathrm{~cm}$ & $\begin{array}{l}\text { Buzzer aktif, LED nyala, } \\
\text { LCD mendeteksi }\end{array}$ & $\begin{array}{l}\text { Berhasil mendeteksi } \\
\text { gas }\end{array}$ \\
\hline & & $50 \mathrm{~cm}$ & $\begin{array}{l}\text { Buzzer nonaktif, LED } \\
\text { tidak nyala, LCD tidak } \\
\text { mendeteksi }\end{array}$ & $\begin{array}{l}\text { Gagal mendeteksi } \\
\text { gas }\end{array}$ \\
\hline \multirow{4}{*}{3} & \multirow{4}{*}{$\begin{array}{l}\text { Pengujian jarak deteksi } \\
\text { pada sensor MQ6 }\end{array}$} & $10 \mathrm{~cm}$ & $\begin{array}{l}\text { Buzzer aktif, LED nyala, } \\
\text { LCD mendeteksi }\end{array}$ & $\begin{array}{l}\text { Berhasil mendeteksi } \\
\text { gas }\end{array}$ \\
\hline & & $20 \mathrm{~cm}$ & $\begin{array}{l}\text { Buzzer aktif, LED nyala, } \\
\text { LCD mendeteksi }\end{array}$ & $\begin{array}{l}\text { Berhasil mendeteksi } \\
\text { gas }\end{array}$ \\
\hline & & $30 \mathrm{~cm}$ & $\begin{array}{l}\text { Buzzer aktif, LED nyala, } \\
\text { LCD mendeteksi }\end{array}$ & $\begin{array}{l}\text { Berhasil mendeteksi } \\
\text { gas }\end{array}$ \\
\hline & & $40 \mathrm{~cm}$ & $\begin{array}{l}\text { Buzzer nonaktif, LED } \\
\text { tidak nyala, LCD tidak } \\
\text { mendeteksi }\end{array}$ & $\begin{array}{l}\text { Gagal mendeteksi } \\
\text { gas }\end{array}$ \\
\hline
\end{tabular}




\section{f. Analisis Kerja Sensor}

Ketika sensor dipanaskan pada suhu tertentu dalam hal ini bahannya adalah kristal oksida logam yaitu Stanni oksida $\left(\mathrm{SnO}_{2}\right)$, oksigen akan menempel pada bagian permukaan dari kristal tersebut dengan muatan negatif. Pada saat transfer elektron elektron donor ke bagian oksigen yang teradsorpsi terbentuklah sebuah lapisan ruang dari bagian sensor yang bermuatan positif, akibatnya sebuah potensial permukaan terbentuk yang dapat menghambat aliran elektron yang berlangsung. Di dalam sensor, pada bagian-bagian penghubung dialiri oleh arus listrik, dimana oksigen yang teradsorpsi membentuk potensial permukaan yang dapat menghambat pergerakan dari muatan-muatan elektron bebas. Akibat dari potensial permukaan ini adalah adanya tahanan listrik yang tejadi. Gambar 11 menunjukkan model potensial permukaan antar penghubung pada keadaan tanpa gas.

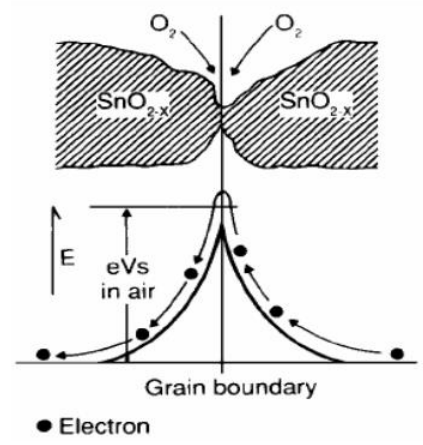

Gambar 11. Model penghalang pada keadaan tanpa gas (sumber: Oktorizal,2010)

Ketika adanya gas lain di lingkungan sumber, oksigen yang bermuatan negatif pada lapisan awal permukaan sensor menjadi menurun dalam hal ini kerapatannya. Dengan menurunnya kerapatan menyebabkan ketinggian potensial permukaan menjadi berkurang, maka resistansi sensor akan ikut menurun [7]. Gambar 12 adalah model penghalang pada keadaan adanya gas.

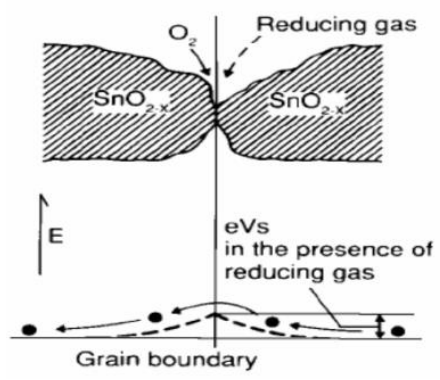

Gambar 12. Model penghalang pada keadaan adanya gas(sumber: Oktorizal,2010)
Setiap sensor memiliki bahan lapisan yang berbeda-beda, dalam pengujian ini sensor yang digunakan adalah sensor TGS2610. Bahan penyusun lapisan sensor adalah $\mathrm{SnO}_{2} . \mathrm{SnO}_{2}$ merupakan bahan semikonduktor yang banyak dipakai dalam hal ini sensor gas keluaran figaro, bahan semikonduktor banyak digunakan pada berbagai jenis sensor gas dikarenakan memiliki sifat fisik seperti stabilitas kimia, transfer muatan dan sifat listrik yang baik [8]. Bahan dari $\mathrm{SnO}_{2}$ memiliki sifat serapan gas yang baik [9]. Ketika sebuah sensor dipanaskan, ada dua pengaruh utama yang akan terjadi pada sebuah sensor yaitu aktifitas molekul akan naik dan terjadinya konversi aliran udara pada sensor. Sensor TGS2610 sangat sensitif dan cara kerjanya terbilang cukup sederhana, ketika sumber gas LPG disemprotkan ke sensor maka molekul gas LPG akan menempel pada permukaan sensor dan mengakibatkan terjadinya perpindahan elektron secara berlawanan dengan oksigen, peristiwa ini akan mengakibatkan tingginya kerapatan elektron dan konduktivitas sensor. Ketika sensor didekati oleh gas butana maka konduktivitas akan meningkat, sebaliknya jika di udara bersih maka konduktivitas akan menurun. Sensor TGS2610 memiliki kinerja yang berbeda dari sensor MQ2 dan MQ6 karena dari 2 parameter yang diuji ternyata TGS2610 memiliki kelebihan dalam hal pembacaan deteksi yang cepat dan jarak deteksi yang jauh.

\section{Kesimpulan}

Berdasarkan penelitian ini, telah dilakukan perancangan, pembuatan dan perbandingan kinerja sensor TGS2610, MQ2, dan MQ6. Dapat disimpulkan bahwa :

1. Pada pengujian waktu respon didapatkan hasil bahwa waktu respon rata-rata 0,03 detik untuk sensor TGS2610 dan 0,16 detik untuk sensor MQ6 serta 0,13 detik untuk sensor MQ2.

2. Pada pengujian jarak terjauh diperoleh hasil bahwa sensor TGS2610 dapat mendeteksi gas pada jarak $50 \mathrm{~cm}$, MQ6 mampu mendeteksi gas pada jarak $30 \mathrm{~cm}$ dan MQ2 mampu mendeteksi gas pada jarak $40 \mathrm{~cm}$.

\section{Daftar Pustaka}

[1] Herminawan, F. W. 2009. Prototype Sistem Peringatan Dini Kebocoran Liquified Petroleum Gas Menggunakan Sensor TGS2610. Jurnal PROSISKO. 14:1.

[2] Triyandana, M. I. 2015. Pendeteksi Gas LPG Dan Metana Menggunakan Sensor TGS2610 dan TGS2611 Berbasis 
Mikrokontroler ATMega328P. Jurnal Coding. 03:11-21.

[3] Iksal. 2016. Rancang Bangun Protoype Penanganan Dini Dan Pendeteksi Kebocoran Gas LPG Berbasis Mikrokontroler Melalui SMS. Jurnal PROSISKO. 3:26.

[4] Putra, M. 2017. Rancang Bangun Alat Pendeteksi Kebocoran Gas LPG Dengan Sensor MQ6 Berbasis Mikrokontroler Melalui Smartphone Android Sebagai Media Informasi. Jurnal Informatika Mulawarman. 12:1-6.

[5] Kelana, M., Muid, A., dan Nurhasanah, Rancang Bangun Sistem Pengontrol Intensitas Cahaya pada Ruang Baca Berbasis Mikrokontroler ATMEGA16, POSITRON, 5[1]. Pp 5-10, 2015.

[6] Rahardjo, P. 2015. Detektor LPG Menggunakan Sensor MQ2 Berbasis Mikrokontroler ATMEGA 328. E-Jurnal SPEKTRUM. 2:53-57.

[7] Oktorizal, A., 2010, Studi Sensor Gas Berbasis Surface Acoustic Wave Untuk Penerapan Pada Sistem Identifikasi Gas, Universitas Andalas, Padang.

[8] Yadav, B. C., 2011, Solid State Titaniabased Gas Sensor for Liquified Petroleum Gas Detection at Room Temperature, Bull. Matter. Sci., Vol 34, No 7, hal 1639-1644.

[9] Wismadi, T., 2001, Pembuatan dan Karakterisasi Lapisan Tipis Copper Oxide (CuO) Sebagai Sensor Gas, Skripsi, Program S-1 Fisika, Fakultas Matematika dan Ilmu Pengetahuan Alam, Institut Pertanian Bogor, Bogor. 